Received 24.04.2017 Reviewed 26.07.2017 Accepted 13.09.2017

A - study design

B - data collection

C - statistical analysis

D - data interpretation

$\mathbf{E}$ - manuscript preparation

F - literature search

\section{Assessment of two loss methods for estimation of surface runoff in Zaafrania urban catchment, North-East of Algeria}

\author{
Yacina DAHDOUH ${ }^{\mathrm{ABCDEF} \bowtie}$, Lahbassi OUERDACHI $^{\mathrm{ADEF}}$
}

Badji Mokhtar-Annaba University, Laboratory of Hydraulics and Hydraulic Constructions, P.O. BOX 12, 23000 Annaba, Algeria; e-mail: yacina-23@hotmail.fr, ouerdach@univ-annaba.org

For citation: Dahdouh Y., Ouerdachi L. 2018. Assessment of two loss methods for estimation of surface runoff in Zaafrania urban catchment, North-East of Algeria. Journal of Water and Land Development. No. 36 p. 37-43. DOI: 10.2478/jwld-2018-0004.

\begin{abstract}
Surface runoff is a major problem in urban catchments; its generation is always related to the amount of effective rainfall dropped over the surface, however in urban catchments the process is considerably altered by the emergence of impervious areas. In this study the Soil Consevation Service - curve number (SCS-CN) and the Green-Ampt loss methods were used in rainfall-runoff modelling in the Zaafrania urban catchment which is located in Annaba city in the north east of Algeria. The two loss methods were carried out within Hydrologic Engineering Center - Hydrologic Modelling System (HEC-HMS), the choice of the appropriate method for simulating runoff hydrographs in the study area was made by comparing the simulated hydrographs versus observed data using visual inspection and statistical analysis. The results indicate that SCS-CN loss method fit better in the case of 100 years return period NSE (0.462) than in 10 years NSE $(0.346)$ and the results of calibration of GreenAmpt loss method for the 100 years return period NSE (0.417) provide best fit than the case of 10 years NSE $(0.381)$. Furthermore, the results of both return periods (10 and 100 years) of SCS-CN loss method provide best fit than the results of return periods (10 and 100 years) of Green-Ampt loss method. It could be concluded that SCS-CN method is preferred to the Green-Ampt method for event based rainfall-runoff modelling.
\end{abstract}

Key words: Green-Ampt method, HEC-HMS method, rainfall-runoff modelling, SCS-CN, surface runoff, urban catchment

\section{INTRODUCTION}

Urbanization has a large impact on the hydrologic cycle increasing the likelihood of flooding [AZAM et al. 2017]. In fact, the deforestation and the development of impervious areas due to the urbanization and reduce the infiltration process which implies faster and greater runoff [SAGHAFIAN et al. 2008]. If these effects are not taken into consideration, disastrous damages to human life and property can occur.

The growing degree of urbanization leads to the increase of the number of impermeable surfaces in the catchment basin. Consequently often occurring tem- pestuous rain falls in spring are the main cause of rising violent surface water flows [RADECKI-PAWLIK et al. 2014]. These problems of the water scare region are not only caused by low or unpredictable rainfall pattern but also due to the lack of capacity to conserve and manage the available rainwater in a sustainable manner [SKHAKHFA, OUERDACHI 2016].

A variety of hydrological models have been developed and applied to simulate the rainfall-runoff process in urban areas, including SWMM, MIKE, HSPF, STORM, and HEC-HMS [HAFEZPARAST et al. 2013; LAOUACHERIA, MANSOURI 2015; LEE et al. 2010; ROSSMAN 2009]. 
In this study the Hydrologic Engineering CenterHydrologic Modelling System (HEC-HMS) model was used to simulate runoff volume using two loss methods namely the Soil Conservation Service Curve Number (SCS-CN) method and the GreenAmpt method. The SCS-CN method is amongst the most applied methods in the world for estimating losses and direct runoff from a given rainfall event. The curve number $(C N)$ which is a crucial parameter in the application of the SCS-CN method is often determined in Geographic Information System (GIS) environment [BANSODE, PATIL 2014; BHURA et al. 2015]. This method is based on a rainfall-runoff model for quantifying direct runoff [Li et al. 2015].

The Green-Ampt method is considered as one of the most complicated methods for better estimating the impacts of land use on runoff as indicated by [WILCOX et al. 1990]. Unlike the SCS-CN method, the use of the Green-Ampt method requires several additional parameters which are mainly related to the catchment characteristics. These parameters have a considerable influence on the infiltration process. Some studies have been conducted on CN's performance at Green and Ampt [NEARING et al. 1996].

The objective of this study is to assess the results of the SCS-CN and the Green-Ampt methods in estimating surface runoff and flooding in the small urban catchment of Zaafrania for two return periods (10 and 100 years) against observed data. In addition sensitivity analysis and model performance due to various data sources are also highlighted in this study.

\section{MATERIALS AND METHODS}

\section{STUDY AREA AND DATA}

This study was conducted in the Zaafrania watershed, which is located in the North-East region of Annaba in Algeria (Fig. 1), between $7^{\circ} 44^{\prime} 27.58^{\prime \prime}$ E to $7^{\circ} 44^{\prime} 55.06^{\prime \prime} \mathrm{E}$ longitudes and $36^{\circ} 54^{\prime} 53.87^{\prime \prime} \mathrm{N}$ to $36^{\circ} 54^{\prime} 39.72^{\prime \prime} \mathrm{N}$ latitudes. The elevations in the watershed range from 10 to $230 \mathrm{~m}$ (Fig. 1). The data used in this study consisted on rainfall data and hydrometric observations which were collected from the National Agency of Water Resources (Fr. Agence Nationale des Ressources Hydrauliques - ANRH), were selected the biggest daily maximum precipitation for 15 years max.

\section{HYDROLOGICAL MODEL}

The Hydrologic Engineering Center's-Hydrologic Modelling System (HEC-HMS) was selected to simulate the rainfall-runoff model. It is a semi-distributed, event based model, which dividing the catchment into sub-basins, computing runoff response in each subbasin, and routing the river flow to the outlet. HEC-HMS has been extensively used in assessing the effects of land use changes and urbanization on hydro-

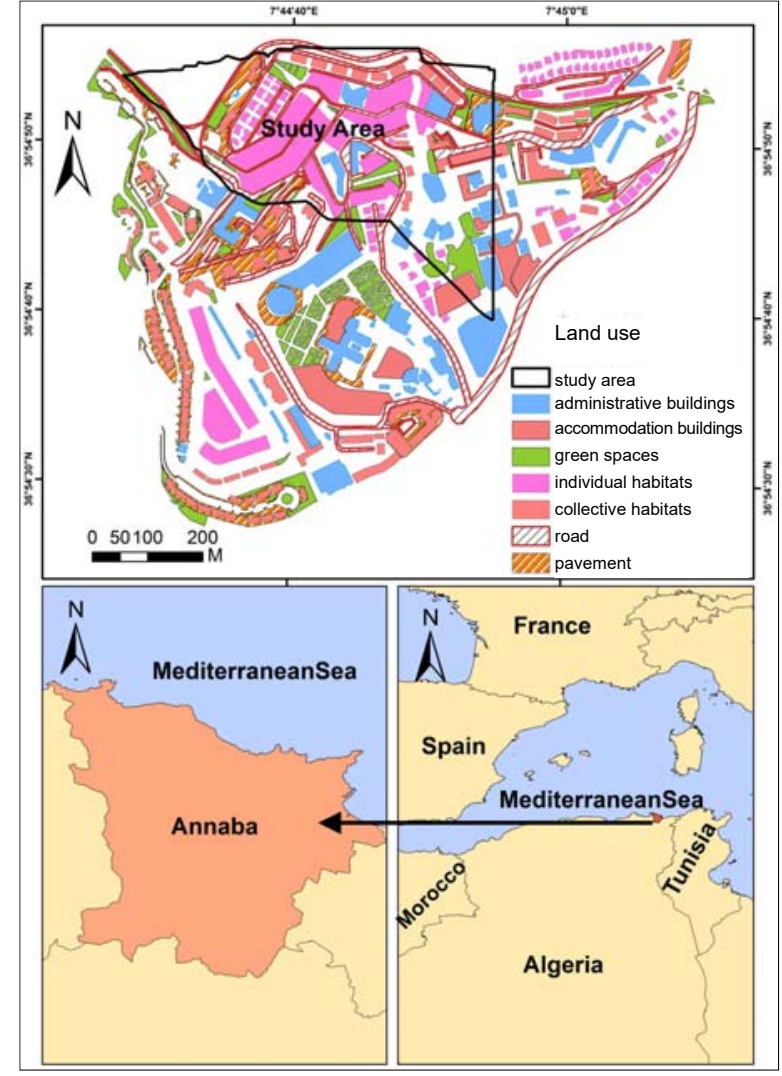

Fig. 1. Location and land use of the study area; source: own elaboration

logical processes [ALI et al. 2011; DU et al. 2012; LAOUACHERIA, MANSOURI 2015; ZOPE et al. 2015]. It is the physically based and conceptual semi distributed model designed to simulate the rainfall runoff processes in a wide range of geographic areas such as large river basin water supply and flood hydrology to small urban and natural watershed runoff. HEC-HMS uses separate models to represent each component of the runoff process, including models that compute runoff volume, models of direct runoff, and models of base flow [MOKHTARI et al. 2016].Two loss methods were chosen to estimate rainfall-runoff model, which are the Soil Conservation Service-Curve Number (SCS-CN) method and the Green-Ampt method. Channel flow was calculated using the Muskingum routing method.

\section{SCS-CN METHOD}

The Soil Consevation Service - curve number (SCS-CN) method [NRCS 2008] is a widely rainfallrunoff model which is based on the water balance calculation by supposing that the ratio of the real quantity of direct runoff to the maximum possible runoff is equal to the ratio of the amount of real infiltration to the quantity of the potential maximum retention and that the amount of initial abstraction is some fraction of the potential maximum retention. This method is given by Equations (1), (2) and (3). 


$$
\begin{gathered}
Q=\frac{\left(P-I_{a}\right)^{2}}{\left(P-I_{a}\right)+S} \\
S=\frac{25400}{C N}-254 \\
I_{a}=\lambda S
\end{gathered}
$$

Where: $Q=$ runoff depth $(\mathrm{mm}) ; P=$ gross rainfall depth (mm); $I_{a}=$ initial abstraction $(\mathrm{mm}) ; S=$ potential retention $(\mathrm{mm})$.

The only one parameter, named curve number $(C N)$, is related to land cover, soil type and antecedent moisture condition, while the constant $\lambda$ value should be fixed to 0.2 .

\section{GREEN-AMPT METHOD}

Green-Ampt method is also used to calculate the infiltration and loss rate in runoff modelling. The Green and Ampt relations are simplified representations of the infiltration loss method and also are considered as a preferred method to compute vertical water flow in soil during rainfall events [CHU 1978]. It is a function of the soil suction head, porosity, hydraulic conductivity and time. The general formula of GreenAmpt method is given below:

$$
f(t)=K\left(\frac{\psi \Delta \theta}{F(t)}+1\right)
$$

Where: $f(t)=$ the infiltration rate $\left(\mathrm{mm} \cdot \mathrm{h}^{-1}\right) ; K=$ the hydraulic conductivity $\left(\mathrm{mm} \cdot \mathrm{h}^{-1}\right) ; \psi=$ the wetting front soil suction head (mm); $\Delta \theta=$ the change in moisture content; $F(t)=$ the cumulative infiltration $(\mathrm{mm}) ; t=$ time (h).

$F(t)$ is estimated by:

$$
F(t)=K t+\psi \Delta \theta \ln \left(1+\frac{F(t)}{\psi \Delta \theta}\right)
$$

\section{DATA PREPARATION}

Digital elevation model (DEM) of $90 \mathrm{~m}$ resolution was processed and used to generate the stream network and to define the sub-catchments. Hydrologic and topographic parameters were calculated as the model inputs.

Soil types were converted into hydrologic soil groups. There is one rainfall station throughout the catchment, although the precipitation in each subcatchment was estimated by the frequency storm method. Precipitation data of rainfall events were recorded in 10 min time interval, the model simulations were also operated on 10 min step consequently.

Land use data was obtained by digitizing the satellite image of the study area, and was reclassified into seven types: accommodation buildings, administrative buildings, green spaces, pavements, roads, collective habitats and individual habitats (Fig. 1).

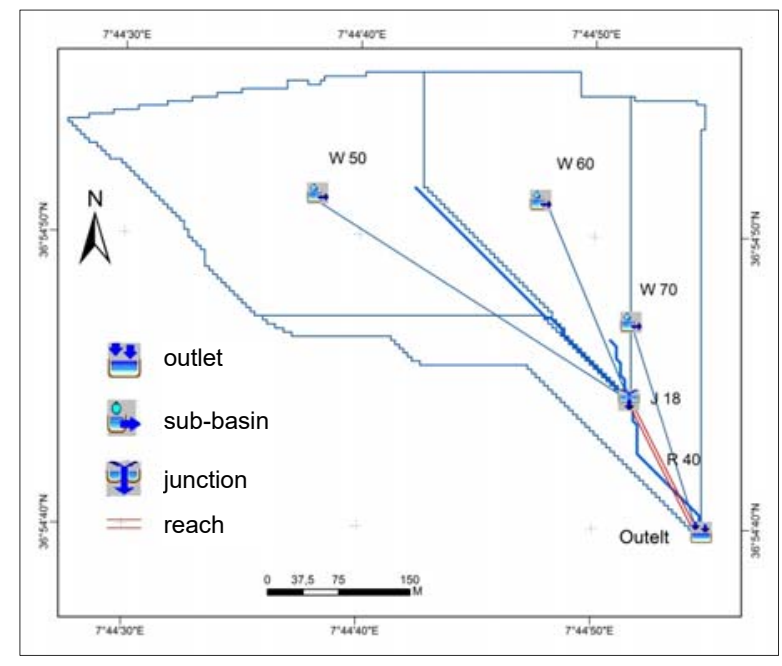

Fig. 2. Sub-catchment of the study area under Hydrologic Engineering Center - Hydrologic Modelling System (HEC-HMS); source: own elaboration

As illustrated in Figure 2, the catchment was derived within Hydrologic Engineering Center - Hydrologic Modelling System (HEC-HMS) into 3 subbasins which are connected with a junction; a sink was used to represent the outlet of a basin (with inflow and without outflow).

\section{STATISTICAL ANALYSIS}

The objective of this section is to analyse the sensitivity of two models towards the values of the parameters implied in the simulations. To evaluate the flexibility of the rainfall-runoff model in this study case, we used Nash-Sutcliffe coefficient of efficiency (NSE), root mean square error (RMSE), correlation coefficient $(R)$ and mean absolute error $(M A E)$.

The NSE was used to assess the goodness-of-fit between the simulated and observed discharge data at the Zaafrania urban catchment outlet. NSE values can range from negative infinity to 1 , where 1 is a perfect match of simulated to observed data. RMSE and MAE, values of 0 indicate a perfect fit. Correlation coefficients $(R)$ ranging from 0.7 and 0.9 indicate the variables which can be considered highly correlated. NSE, $R M S E, R$ and $M A E$ are calculated using the following formulas:

$$
\begin{gathered}
N S E=1-\frac{\sum_{i=1}^{N}\left(Q_{i, \mathrm{obs}}-Q_{i, \mathrm{sim}}\right)^{2}}{\sum_{i=1}^{N}\left(Q_{i, \mathrm{obs}}-\bar{Q}_{\mathrm{obs}}\right)^{2}} \\
R M S E=\left(\frac{\sum_{i=1}^{N}\left(Q_{i, \mathrm{obs}}-Q_{i, \mathrm{sim}}\right)^{2}}{N}\right)^{\frac{1}{2}} \\
R=\frac{\sum_{i=1}^{N}\left(Q_{i, \mathrm{obs}}-\bar{Q}_{\mathrm{obs}}\right)\left(Q_{i, \mathrm{sim}}-\bar{Q}_{\mathrm{sim}}\right)}{\sqrt{\sum_{i=1}^{N}\left(Q_{i, \mathrm{obs}}-\bar{Q}_{\mathrm{obs}}\right)^{2}\left(Q_{i, \mathrm{sim}}-\bar{Q}_{\mathrm{sim}}\right)^{2}}}
\end{gathered}
$$




$$
M A E=\frac{\sum_{i=1}^{N}\left|Q_{i, \mathrm{obs}}-Q_{i, \mathrm{sim}}\right|}{N}
$$

Where: $Q_{i, \text { sim }}=$ the simulated discharge at time $t=i$, $Q_{i, \mathrm{obs}}=$ the observed discharge at time $t=i, Q_{\text {obs }}=$ the average observed discharge, $N=$ the number of observations.

\section{RESULTS AND DISCUSSION}

After the preparation of all the required parameters for the both loss methods (Soil Conservation Service - curve number - SCS-CN and Green-Ampt), the loss methods are used to obtain the direct runoff and peak discharge for each sub-catchment. The Figure 3 illustrates the simulated unit hydrographs for the SCS-CN and Green-Ampt loss methods for two return periods (10 and 100 years).
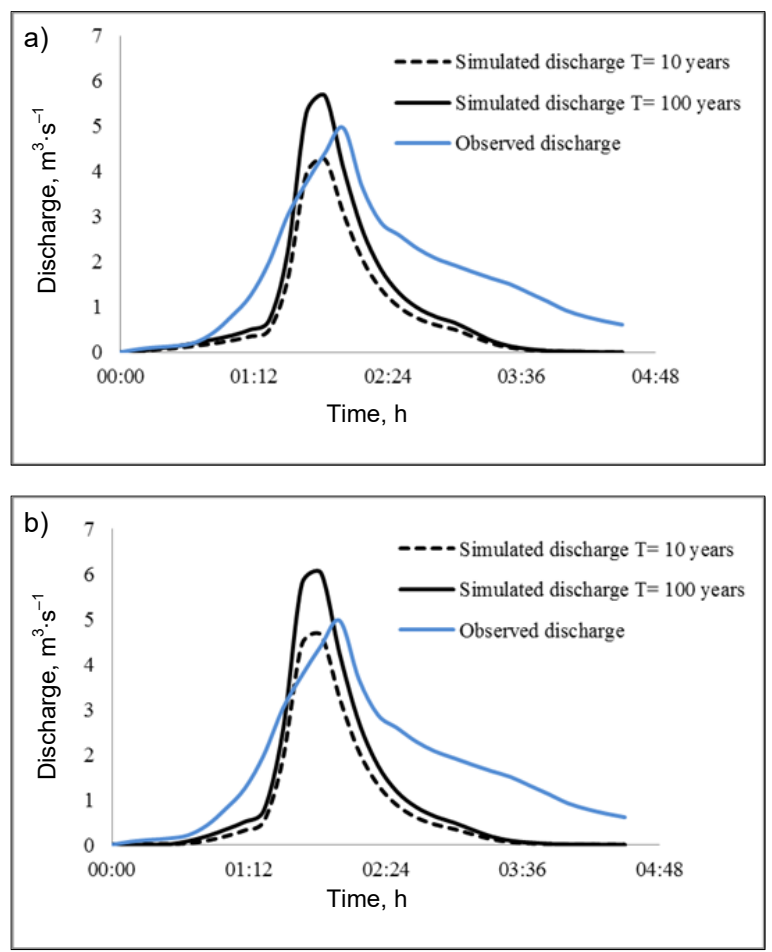

Fig. 3. Simulated unit hydrograph by: a) Soil Conservation Service (SCS) method, b) Green-Ampt method; source: own study

The comparison of the simulated unit hydrograph of the both loss methods for a 10 years return period (Fig. 4a) shows that simulated peak discharge obtained using the SCS-CN method is $4.41 \mathrm{~m}^{3} \cdot \mathrm{s}^{-1}$ while the peak discharge ensuing from the Green-Ampt method is $4.81 \mathrm{~m}^{3} \cdot \mathrm{s}^{-1}$ (Tab. 1) with the same time to peak of about $1 \mathrm{~h} 50 \mathrm{~min}$.

In the case of a return period of 100 years, a slight difference in peak discharges between the two loss methods (Fig. 4b) was obtained with $5.86 \mathrm{~m}^{3} \cdot \mathrm{s}^{-1}$ for the SCS-CN method and $6.18 \mathrm{~m}^{3} \cdot \mathrm{s}^{-1}$ for the GreenAmpt method with the same time to peak of about $1 \mathrm{~h}$ $50 \min$ (Tab. 1)
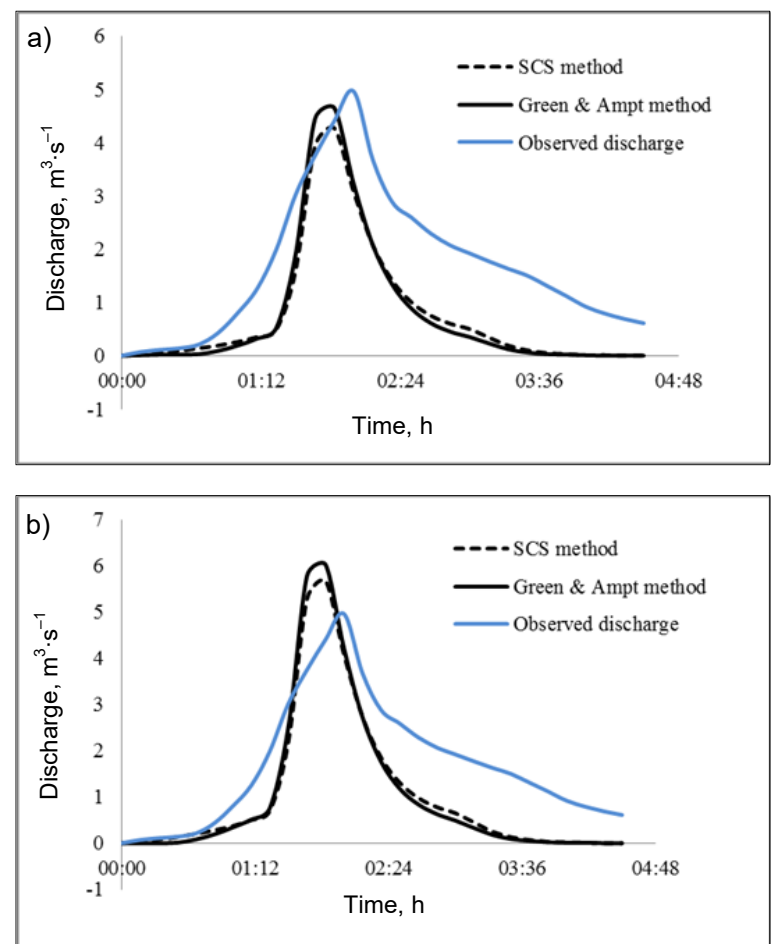

Fig. 4. Simulated unit hydrograph for: a) $T=10$ years, b) $T=100$ years; $\mathrm{SCS}=$ Soil Conservation Service; source: own study

\section{CALIBRATED MODEL OF THE STUDY AREA}

The two models developed in Hydrologic Engineering Center - Hydrologic Modelling System (HEC-HMS) based on two different loss methods were calibrated using observed data of discharges recorded at the outlet of the Zaafrania urban catchment. The calibration shall be carried out taking into account the geographical and hydrological characteristics of the catchment (Tab. 2).

Prior the calibration of model, sensitivity analysis of the parameters of SCS-CN and Green-Ampt loss methods used also to enhance the predict quality of rainfall-runoff modelling used to compute runoff. The Figures 5 and 6 illustrate the differences between

Table 1. Differences between Soil Conservation Service - curve number (SCS-CN) and Green-Ampt methods

\begin{tabular}{|c|c|c|c|c|c|c|c|c|c|c|}
\hline \multirow{2}{*}{$\begin{array}{c}\text { Return } \\
\text { period } \\
\text { year }\end{array}$} & \multicolumn{3}{|c|}{ SCS-CN (1) } & \multicolumn{3}{|c|}{ Green-Ampt (2) } & \multicolumn{3}{|c|}{ Observed (3) } & \multirow[b]{2}{*}{ Results } \\
\hline & $\begin{array}{c}\text { volume } \\
\text { mm }\end{array}$ & $\begin{array}{c}\text { peak discharge } \\
\mathrm{m}^{3} \cdot \mathrm{s}^{-1}\end{array}$ & $\begin{array}{l}\text { time of } \\
\text { peak }\end{array}$ & $\begin{array}{c}\text { volume } \\
\mathrm{mm}\end{array}$ & $\begin{array}{c}\text { peak discharge } \\
\mathrm{m}^{3} \cdot \mathrm{s}^{-1}\end{array}$ & $\begin{array}{l}\text { time of } \\
\text { peak }\end{array}$ & $\begin{array}{c}\text { volume } \\
\mathrm{mm}\end{array}$ & $\begin{array}{c}\text { peak discharge } \\
\mathrm{m}^{3} \cdot \mathrm{s}^{-1}\end{array}$ & $\begin{array}{l}\text { time of } \\
\text { peak }\end{array}$ & \\
\hline 10 & 76.68 & 4.41 & $1 \mathrm{~h} 50 \mathrm{~min}$ & 84.83 & 4.81 & $1 \mathrm{~h} 50 \mathrm{~min}$ & 159.96 & 4.96 & $2 \mathrm{~h} 00 \mathrm{~min}$ & $(1)<(2)<(3)$ \\
\hline 100 & 98.88 & 5.68 & $1 \mathrm{~h} 50 \mathrm{~min}$ & 108.87 & 6.18 & $1 \mathrm{~h} 50 \mathrm{~min}$ & 159.96 & 4.96 & $2 \mathrm{~h} 00 \mathrm{~min}$ & $(3)<(1)<(2)$ \\
\hline
\end{tabular}

Source: own study. 
Table 2. Calibrated parameters for both Soil Conservation Service - curve number (SCS-CN) and Green-Ampt methods

\begin{tabular}{|c|c|c|c|c|c|}
\hline \multirow{2}{*}{ Sub-basin } & \multirow{2}{*}{$\begin{array}{c}\text { SCS unit hydrograph } \\
\text { lag time, min }\end{array}$} & \multirow{2}{*}{$\begin{array}{l}\text { SCS-CN loss method } \\
\text { curve number }(C N)\end{array}$} & \multirow{2}{*}{$\begin{array}{l}\text { Green-Ampt method } \\
\text { conductivity, } \mathrm{mm} \cdot \mathrm{h}^{-1}\end{array}$} & \multicolumn{2}{|c|}{ Routing reach No. R40 } \\
\hline & & & & Muskingum $K, \mathrm{~h}$ & Muskingum $X$ \\
\hline W50 & 7.313 & 91.20 & 1 (clay loam) & \multirow{3}{*}{0.25} & \multirow{3}{*}{0} \\
\hline W60 & 4.640 & 91.27 & 1 (clay loam) & & \\
\hline W70 & 8.096 & 89.16 & 1 (clay loam) & & \\
\hline
\end{tabular}

Explanations: W50, W60 and W70 as in Fig. 2.

Source: own study.
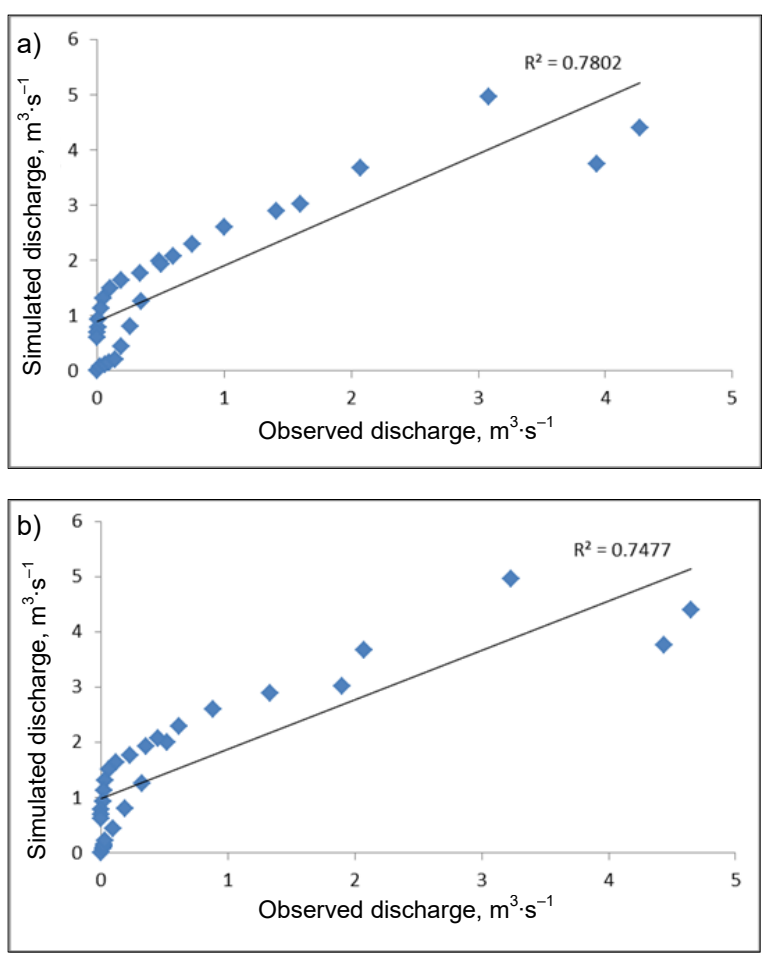

Fig. 5. Comparison of simulated discharge and observed discharge on Soil Conservation Service - curve number method for return period of: a) 10 years, b) 100 years; source: own study

simulated and observed hydrographs for the event of $9^{\text {th }}$ February, 2015, obtained for return periods of 10 years and 100 years in the case of two loss methods (SCS-CN and Green-Ampt).

The correlations between simulated discharges and observed discharges (Figs. 5, 6) give nonlinear relationships, but with acceptable correlation coefficients ranging from 0.85 and 0.9 . This can be explained by the fact that the observed discharges in the period of $9^{\text {th }}$ February, 2015 do not necessarily correspond to the rain falling during the same period and that the surface runoff can indeed be supported by the underground flows due to the rain of the day of $9^{\text {th }}$ February, 2015 or the previous days.

During the calibration values of RMSE, MAE, $N S E$ and $R$ for the SCS-CN loss method were 1.08 $\mathrm{m}^{3} \cdot \mathrm{s}^{-1}, 0.90 \mathrm{~m}^{3} \cdot \mathrm{s}^{-1}, 0.346$ and 0.883 respectively (Tab. 3) for return period of 10 years and the values of RMSE, MAE, NSE and $R$ for the SCS-CN loss method were $0.98 \mathrm{~m}^{3} \cdot \mathrm{s}^{-1}, 0.85 \mathrm{~m}^{3} \cdot \mathrm{s}^{-1}, 0.462$ and $0.880 \mathrm{respec}-$ tively (Tab. 3 ) for return period of 100 years. $R$ also showed that the unit hydrograph for SCS-CN loss
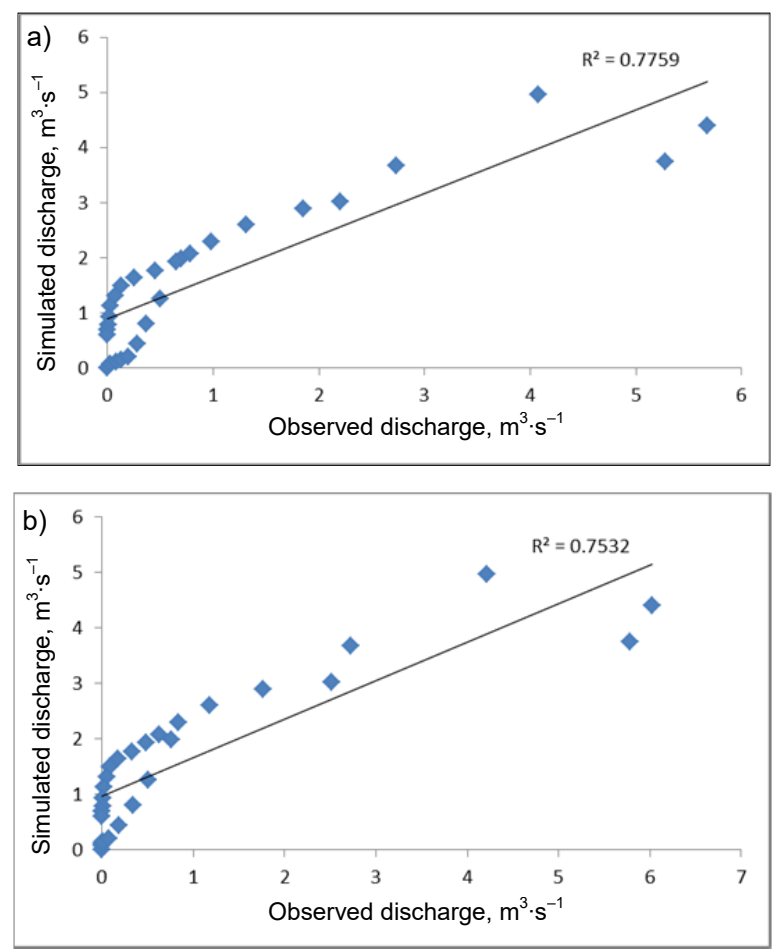

Fig. 6. Comparison of simulated discharge and observed discharge on Green-Ampt method for return period of: a) 10 years, b) 100 years; source: own study

method for the return period of 10 years fits better as compared to the unit hydrograph for SCS-CN loss method for the return period of 100 years (Fig. 5). Hence, NSE showed that the unit hydrograph for SCS$\mathrm{CN}$ loss method for the return period of 10 years fits less than as compared to the unit hydrograph for SCS$\mathrm{CN}$ loss method for the return period of 100 years (Tab. 3).

Table 3. Statistical evaluation of calibrated Soil Conservation Service - curve number (SCS-CN) and Green-Ampt methods

\begin{tabular}{|c|c|c|c|c|}
\hline $\begin{array}{c}\text { Return period } \\
\text { year }\end{array}$ & $R M S E, \mathrm{~m}^{3} \cdot \mathrm{s}^{-1}$ & $M A E, \mathrm{~m}^{3} \cdot \mathrm{s}^{-1}$ & $N S E$ & $R$ \\
\hline \multicolumn{6}{|c|}{ SCS-CN method } \\
\hline 10 & 1.08 & 0.90 & 0.346 & 0.883 \\
\hline 100 & 0.98 & 0.85 & 0.462 & 0.880 \\
\hline \multicolumn{6}{|c|}{ Green-Ampt method } \\
\hline 10 & 1.05 & 0.89 & 0.381 & 0.864 \\
\hline 100 & 1.02 & 0.84 & 0.417 & 0.868 \\
\hline
\end{tabular}

Explanations: $R M S E=$ root mean squared error, $M A E=$ mean absolute error, $N S E=$ Nash-Sutcliffe' efficiency, $R=$ correlation coefficient.

Source: own study. 
In the case of Green-Ampt loss method values of $R M S E, M A E, N S E$ and $R$ were $1.05 \mathrm{~m}^{3} \cdot \mathrm{s}^{-1}, 0.89 \mathrm{~m}^{3} \cdot \mathrm{s}^{-1}$, 0.381 and 0.864 respectively (Tab. 3) for return period of 10 years and for the return period of 100 years the values of RMSE, MAE, NSE and $R$ for the SCS-CN loss method were $1.02 \mathrm{~m}^{3} \cdot \mathrm{s}^{-1}, 0.84 \mathrm{~m}^{3} \cdot \mathrm{s}^{-1}, 0.417$ and 0.868 respectively (Tab. 3 ). $R$ also showed that the unit hydrograph for Green-Ampt loss method for the return period of 10 years fits nearby as compared to the unit hydrograph for Green-Ampt loss method for the return period of 100 years (Fig. 6). Hence, NSE showed that the unit hydrograph for Green-Ampt loss method for the return period of 10 years fits less than as compared to the unit hydrograph for Green-Ampt loss method for the return period of 100 years (Tab. 3).

For the two models run with the both return period of 10 and 100 years, the results in Table 3 indicate that urban catchment simulation considered poor $(0.0<N S E<0.5)$. In the both poor cases, the results are associated with a lack of coincidence in the timing of high or low rainfall amounts and high or low observed discharge responses.

The results for urban catchment simulation demonstrate a serious problem with calibrating only using comparison statistics without examining the shape of the simulated discharge hydrograph relative to the observed discharge hydrograph. The Table 3 indicates that the values of NSE of both models are less than 0.5 , and the verification of the time series indicates a regular $10 \mathrm{~min}$ shift in the observed discharge hydrograph, relative to the simulated discharge hydrograph. The cause of this poor result is difficult to resolve, but if the observed discharge data are shifted backwards by $10 \mathrm{~min}$, the NSE statistic improves to the best.

\section{CONCLUSIONS}

In this study two loss methods were compared in order to select the most suitable for event-based simulation by Hydrologic Engineering Center - Hydrologic Modelling System (HEC-HMS).

In order to determine the effectiveness and relevance of the methods used, we have tried to make a comparison of the results of some correlation coefficients and error indices such as root mean square error (RMSE), mean absolute error (MAE), the NashSutcliffe efficiency (NSE). While, RMSE and MAE of values "0" indicate a perfect fit. NSE of value "1" indicates a perfect correlation.

The obtained results show that the variation of the discharge simulated by the two models is different for both return periods (10 and 100 years), and that the resulting Nash coefficient is (0.346) for the SCS-CN loss method fit less than Green-Ampt loss method with Nash coefficient of $(0.381)$ for return period of 10 years. Hence, in the case of the return period of 100 years, the SCS-CN loss method fit better than Green-Ampt loss method with Nash coefficient of (0.462) and (0.417) respectively. Therefore, the
SCS-CN loss method was chosen as a modelling process that will be generalized throughout the Zaafrania urban catchment.

\section{REFERENCES}

Ali M., Khan S.J., Aslam I., Khan Z. 2011. Simulation of the impacts of land-use change on surface runoff of Lai Nullah Basin in Islamabad, Pakistan. Landscape Urban Plan. Vol. 102. Iss. 4 p. 271-279.

AZAm M., Kim H.S., MaEN J.S. 2017. Development of flood alert application in Mushim stream watershed Korea. International Journal of Disaster Risk Reduction. Vol. 21 p. $11-26$.

Bansode A., PATIL K.A. 2014. Estimation of runoff by using SCS curve number method and arc GIS. International Journal of Scientific and Engineering Research. Vol. 5. Iss. 7 p. 1283-1287.

Bhura C.S., Singh N. P., MORi P.R., PraKash I. 2015. Estimation of surface runoff for Ahmedabad urban area using SCS-CN method and GIS, IJSTE. International Journal of Scientific and Engineering Research. Vol. 1. Iss. 11 p. 2349-2784.

ChU S.T. 1978. Infiltration during unsteady rain. Water Resources Research. Vol. 14. Iss. 3 p. 461-466.

Du J., Qian L., Rui H., ZuO T., Zheng D., Xu Y., CH Y. 2012. Assessing the effects of urbanization on annual runoff and flood events using an integrated hydrological modeling system for Qinhuai River basin, China. Journal of Hydrology. Vol. 464-465 p. 127-139.

Hafezparast M., ARAGHinejad S., EhSAN FAtemi S., BRESSERS H. 2013. A conceptual rainfall-runoff model using the auto calibrated NAM models in the Sarisoo River. Hydrology: Current Research. Vol. 4. Iss. 148 pp. 6. DOI 10.4172/2157-7587.1000148.

Laouacheria F., Mansouri R. 2015. Comparison of WBNM and HEC-HMS for runoff hydrograph prediction in a small urban catchment. Water Resources Management. Vol. 29 p. 2485-2501. DOI 10.1007/s11269015-0953-7.

Lee S.B., Yoon C.G., Jung K.W., Hwang H.S. 2010. Comparative evaluation of runoff and water quality using HSPF and SWMM. Water Science and Technology. Vol. 62. Iss. 6 p. 1401-1409.

Li J., LIU C., WANG Z., LiANG K. 2015. Two universal runoff yield models: SCS vs. LCM. Journal of Geographical Sciences. Vol. 25. Iss. 3 p. 311-318. DOI 10.1007/ s11442-015-1170-2.

Mokhtari E.H., Remini B., HAmoudi S.A. 2016. Modelling of the rain-flow by hydrological modelling software system HEC-HMS - watershed's case of wadi Cheliff Ghrib, Algeria. Journal of Water and Land Development. No. 30 p. 87-100. DOI $10.1515 /$ jwld-2016-0025.

NeAring M.A., LiU B.Y., Risse L.M., Zhang X. 1996. Curve numbers and Green-Ampt effective hydraulic conductivities. Journal of the American Water Resources Association. Vol. 32. No. 1 p. 125-136. DOI 10.1111/j.1752-1688.1996.tb03440.x.

NRCS 2008. National engineering handbook. Part 630. Hydrology. Washington D.C. USDA.

RADECKI-PAWlik A., WalĘGA A., Wojkowski J., PijanowSKI J. 2014. Runoff formation in terms of changes in land use - Mściwojów water reservoir area. Journal of Water and Land Development. No. 23 p. 3-10. DOI 10.1515/jwld-2014-0024. 
Rossman L.A. 2009. Storm water management model user's manual version 5.0. EPA/600/R-05/040. Cincinnati, Ohio. National Risk Management Research Laboratory. USEPA.

Saghafian B., FarazjoO H., Bozorgy B., Yazdandoost F. 2008. Flood intensification due to changes in land use. Water Resources Management. Vol. 22 p. 10511067.

SKHAKHFA I.D., OUERDACHI L. 2016. Hydrological modelling of wadi Ressoul watershed, Algeria, by HEC-HMS model. Journal of Water and Land Development. No. 31 p. 139-147. DOI 10.1515/jwld-2016-0045.

Wilcox B.P., Rawls W.J., BrakensieK D.L., Wight J.R. 1990. Predicting runoff from Rangeland catchments: A comparison of two models. Water Resources Research. Vol. 26. No. 10 p. 2401-2410.

Zope P.E., ElDHO T.I., JOTHIPRAKASH V. 2015. Impacts of urbanization on flooding of coastal urban catchment: A case study of Mumbai City, India. Natural Hazards. Vol. 75 p. 887-908.

\section{Yacina DAHDOUH, Lahbassi OUERDACHI \\ Ocena dwóch metod szacowania spływu powierzchniowego w miejskiej zlewni Zaafrania, pólnocnowschodnia Algieria}

\section{STRESZCZENIE}

Spływ powierzchniowy jest głównym problemem w miejskich zlewniach. Spływ jest zawsze uzależniony od opadu, jednak w miejskich zlewniach proces ulega znaczącej modyfikacji z powodu obecności powierzchni nieprzepuszczalnych. W badaniach prezentowanych w niniejszej pracy zastosowano dwie metody - SCS-CN (ang. Soil Coservation Service - curve number) i Green-Ampt do modelowania relacji opad-odpływ w miejskiej zlewni Zaafrania na terenie miasta Annaba na północnym wschodzie Algierii. Obie metody realizowano w ramach modelu HEC-HMS. Odpowiednią metodę symulowania hydrogramu odpływu dobrano na podstawie wizualnej oceny i analizy statystycznej. Wyniki dowodzą, że metoda SCS-CN dawała lepsze dopasowanie w przypadku stuletniego okresu powtarzalności $(N S E=0,462)$ niż w przypadku okresu dziesięcioletniego $(N S E=0,346)$. Wyniki kalibracji metodą Green-Ampt zapewniały lepsze dopasowanie dla stuletniego niż dla dziesięcioletniego okresu powtarzalności (NSE odpowiednio 0,417 i 0,381). Ponadto wyniki metody SCS-CN dla obu okresów (10 i 100 lat) wykazywały lepsze dopasowanie niż wyniki uzyskane za pomocą metody GreenAmpt dla tych okresów. Można wnioskować, że metoda SCS-CN ma przewagę nad metodą Green-Ampt w modelowaniu relacji opad-odpływ w odniesieniu do poszczególnych zdarzeń.

Słowa kluczowe: metoda Green-Ampt, metoda HEC-HMS, modelowanie relacji opad-odptyw, SCS-CN, sptyw powierzchniowy, zlewnia miejska 